\title{
PEMBERDAYAAN ANAK PANTI ASUHAN AN-NAHL DAN YAUMIHA DI KABUPATEN SRAGEN MELALUI KETRAMPILAN BETERNAK AYAM RAS PETELUR
}

\author{
Ratih Dewanti ${ }^{1)}$ dan Sudiyono ${ }^{1)}$ \\ 1) Fakultas Pertanian, Universitas Sebelas Maret, Surakarta
}

\begin{abstract}
ABSTRAK
Kegiatan IbM ini dilaksanakan di Panti Asuhan An-Nahl dan Yaumiha di Kabupaten Sragen. Metode yang digunakan adalah dengan memberikan penyuluhan, pelatihan, dan pendampingan pemeliharaan ayam ras petelur, menyediakan peralatan lengkap, pelatihan pemasaran dan pembukuan sederhana serta pengolahan kotoran. Target luaran yang diharapkan adalah membentuk anak panti asuhan yang mandiri secara ekonomis, dan produksi telur ayam ras dari panti yang berkelanjutan. Dalam kegiatan ini di introduksikan kandang bateray 96 kotak, tempat pakan, nipple drinker, eggtray, ayam pullet brown leghorn strain Lohman 96 ekor dan pakan ayam ras petelur. Dari hasil quisioner penyuluhan terjadi peningkatan hasil nilai jawaban benar (pengetahuan meningkat) sesudah penyuluhan yaitu 219 point dibandingkan sebelum penyuluhan 118 point. Puncak produksi telur pada umur ayam 30 minggu sebesar $98 \%$. Penjualan telur perkilo dengan harga Rp.17.000-Rp.20.000/kg. Analisis usaha memberikan keuntungan bersih rata-rata Rp.23.000,-/hari. Melalui kegiatan ini, kemampuan dan ketrampilan anak panti asuhan An-Nahl dan Yaumiha mengalami peningkatan dan diharapkan mandiri secara ekonomis. Rencana tahapan berikutnya untuk kedua mitra sendiri adalah ingin menambah populasi ayam ras petelur dengan membeli bibit baru, untuk memperbesar usaha.
\end{abstract}

Kata Kunci: Ayam Ras Petelur, Beternak, Panti asuhan, An-Nahl dan Yaumiha 


\section{ABSTRACT}

IbM activity was held at the An-Nahl and YAUMIHA orphanage Sragen. The method were counseling, training, and mentoring maintenance layer, providing complete equipment, marketing and management administration and composting. The target of outcomes are resulting child in orphanage which economically independent, and sustainable of layer egg production. There were 96 bateray cages, place of feed, nipple drinker, eggtray, 96 Brown Leghorn pullet and layer feed given to orphanage. From the results of quisioner counseling increased the value of correct answers (knowledge increased) after counseling was 219 points compared before the 118 point extension. Peak production of eggs at 30 weeks of layer age of 98\%. Sales of perkilo eggs with the price of Rp.17.000-Rp.20.000/kg. Business analysis with a net profit of Rp. 23.000,-per day. Through these activities, students' abilities and skills An-Nahl and YAUMIHA orphanage have increased and are expected to be economically self-sufficient. The next plan is for both the partners increase the population of layer by buying pullet in order to expand the business.

Keywords: Layer, Farming Skills, Orphanage, An-Nahl and YAUMIHA 


\section{PENDAHULUAN}

\section{A. LATAR BELAKANG}

Ayam ras petelur sangat potensial dikembangkan untuk diambil telur dan dagingnya dengan produksi utama adalah telur. Diantara semua jenis unggas petelur, ayam Ras petelur termasuk unggas penghasil telur terbesar pertama dan dengan harga termurah dibandingkan telur unggas lain misalnya itik, ayam kampung dan entok. Ayam Ras petelur saat ini sudah mulai bertelur pada umur 20 minggu dan akan terus bertelur sampai diafkir pada umur 75 minggu. Telur ayam merupakan sumber protein hewani yang bergizi tinggi dengan kandungan protein telur $12,7 \%$, dan kandungan lemak 11,3\% (yang lebih rendah dari lemak telur itik 14,5\%), rasa enak serta harga yang relatif murah sehingga menjadi prioritas pilihan yang paling terjangkau sebagai sumber protein hewani bagi keluarga (Kementerian kesehatan RI, 2010). Keuntungan beternak ayam ras petelur adalah tidak memerlukan ketrampilan khusus, serta permintaan telur ayam ras yang stabil bahkan mengalami peningkatan setiap tahunnya. Selain itu, saat ini dengan semakin menjamurnya usaha cake and bakery yang salah satu bahan utamanya adalah telur, maka permintaan telur semakin bertambah.

Mitra 1 Panti Asuhan An-Nahl berdiri pada tahun 1996 beralamat di Jl. Bengawan Solo 19, Kampung Pecing, Sragen Tengah, Kabupaten Sragen. An-Nahl diketuai oleh Bapak Muhajir Sulthon. Panti asuhan ini dirintis oleh beberapa anak muda yang peduli masalah sosial. Saat ini An-Nahl mengasuh 40 anak yatim piatu yang berasal dari Kabupaten Sragen, Karanganyar, Ngawi, Purwodadi dan sekitarnya. Anak Panti yang menginap di Panti asuhan berjumlah 30 anak (yang 10 anak pulang kerumah). Mitra 2 Panti Asuhan Yaumiha berdiri pada tahun 2015 beralamat di Jl. Raya Sukowati Km. 38 Kranggan, Ngepos, Sidoharjo Sukowati dengan jumlah anak asuh 10 anak yatim piatu (karena baru setahun berdiri). Panti asuhan Yaumiha dipimpin oleh Bapak Sofwan. Anak-anak 
Panti asuhan An-Nahl dan Yaumiha yang mempunyai kemampuan merupakan anak-anak yatim piatu yang beternak ayam layer secara produktif sudah tidak memiliki kedua orang tua. sehingga mandiri secara ekonomis, dan Mereka mempunyai nasib yang sangat produksi telur ayam ras dari panti menyedihkan, karena selain kekurangan asuhan yang berkelanjutan.

kasih sayang dari kedua orang tua, mereka juga menjadi bingung harus ikut siapa. Bagi yang masih beruntung, mereka masih bisa ikut nenek kakek atau bibi dan paman. Akan tetapi apabila keluarga besarnya tidak peduli, banyak keluarga besar yang menitipkan di panti asuhan, kemudian ditinggal begitu saja, tidak pernah menengok sekalipun, apalagi memberikan perhatian dan santunan materi. Banyak pihak keluarga yang seperti lepas tangan. Padahal mereka tidak mungkin selamanya menghuni Panti asuhan, mereka harus belajar ketrampilan usaha, sehingga saat keluar dari panti, mereka bisa mandiri dan tidak tergantung dengan orang lain.

\section{Tujuan dan Manfaat}

Tujuan dari pengabdian ini adalah membentuk anak panti asuhan

\section{METODE PENGABDIAN}

Kegiatan pengabdian ini dilakukan dengan metode penyuluhan, pendampingan, pelatihan manajemen pemeliharaan dan produksi ayam layer serta pemasaran telur.

\section{HASIL PENGABDIAN DAN PEMBAHASAN}

Program IbM ini dilaksanakan di Kabupaten Sragen dengan melibatkan dua kelompok mitra yaitu Panti asuhan An-Nahl dan YAUMIHA di Kabupaten Sragen Jawa Tengah. Dalam pelaksanaan pelatihan ada 35 peserta yang berasal dari kedua Panti ditambah dengan guru pendamping.

Kegiatan yang dilaksanakan meliputi introduksi kandang bateray, nipple drinker, ayam pullet, obatobatan, vaksin, eggtray, pakan grower, 
dan pra layer ayam petelur. Pemeliharaan ayam layer dilakukan dari umur 18 minggu (pralayer) sampai 80 minggu (afkir). Kandang ayam yang di introduksikan berupa kandang bateray bahan besi dimana setiap kotak diisi satu ekor ayam. Jumlah keseluruhan adalah 96 kotak (setiap mitra 48 kotak). Jumlah keseluruhan ayam pullet yang diberikan adalah 96 ekor. Alas kandang bateray dibuat dari rangka kayu. Tempat pakan dari peralon 5 Dim sedangkan tempat minum berupa nipple drinker (minum otomatis). Di Panti asuhan An-Nahl, kandang tersebut ditata di sebuah ruangan dibelakang panti dengan atap genting tanpa tembok sehingga udara segar mudah keluar masuk. Sedangkan untuk di Panti asuhan Yaumiha kandang beratapkan asbes dengan tembok separuh di satu sisi. Puncak produksi telur dicapai pada minggu ke30 dengan produksi telur (Hen Day Average/HDA) puncak sampai 98\%. Photo-photo terlampir

\section{a. Kegiatan Penyuluhan dan Pelatihan}


Gambar 1. Penyuluhan beternak ayam ras petelur di Panti asuhan Yaumiha Sragen.



Gambar 2. Foto bersama setelah penyuluhan 


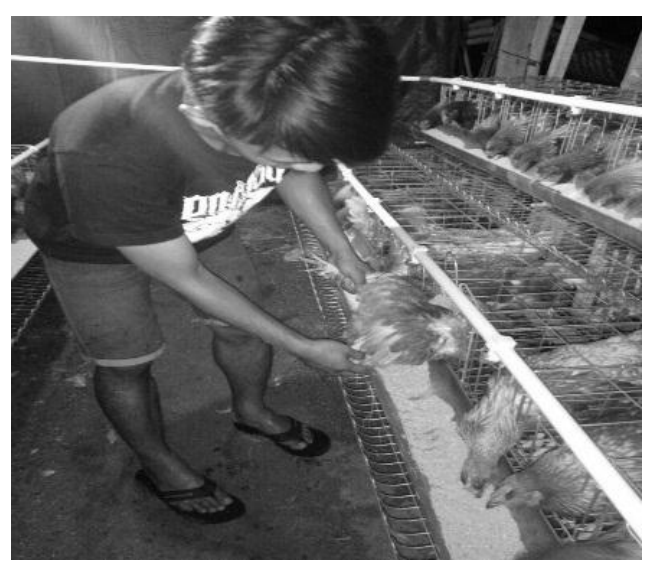

Gambar 3. Ayam masuk

Kegiatan penyuluhan dilakukan untuk mentransfer Iptek dari Tim kepada kelompok sasaran untuk memecahkan persoalan yang dihadapi. Penyuluhan sudah dilakukan oleh Tim pada tanggal 20 Mei 2017 pukul 10.00 sampai 13.00 WIB di Panti asuhan Yaumiha Sragen. Penyuluhan mengundang seorang narasumber Ir.Sudiyono, MS yang berkompeten dibidang ayam layer dan nutrisi pakan. Penyuluhan meliputi manajemen pemeliharaan, pakan, perkandangan, pemeliharaan bibit dan penyakitpenyakit yang sering menjangkiti ayam layer. Penyuluhan diikuti kurang lebih 30 orang meliputi anak panti asuhan
Yaumiha dan An-Nahl beserta guru pendamping. Menurut Amanah (2007) penyuluhan merupakan ilmu dan gerakan transformasi masyarakat melalui pengembangan potensi yang dimiliki dengan pendekatan edukasi, melakukan upaya penyelesaian masalah, menuju tatanan kehidupan yang lebih bermutu dan bermartabat. Peningkatan pengetahuan merupakan satu aspek mendasar yang dijadikan parameter keberhasilan penyuluhan. Pengukuran pengetahuan peserta sebelum dan sesudah penyuluhan merupakan salah satu cara evaluasi terhadap efektivitas peran dan kegiatan penyuluhan. Untuk itu dalam kegiatan ini dilakukan pre test dan post test.

Anak-anak Panti Asuhan secara fisik sangat bisa mengerjakan pekerjaan usaha ternak secara maksimal. Karakteristik peserta penyuluhan seluruhnya adalah Anak panti asuhan An-Nahl dan Yaumiha.

Sebelum dan sesudah penyuluhan dilakukan pembagian quisioner. Dari hasil quisioner 
didapatkan data bahwa setelah penyuluhan tingkat jawaban yang betul mengalami kenaikan yang cukup signifikan yaitu untuk An-Nahl dari 47 menjadi 85 point sedangkan untuk Yaumiha dari 91 menjadi 134 point. Hal ini menggambarkan bahwa dengan diadakannya penyuluhan ternyata dapat meningkatkan pengetahuan dan wawasan anak panti asuhan.

\section{Pelatihan Pengolahan Telur dan Pembuatan Kompos.}

Selain pelatihan pemeliharaan ayam dan produksinya, tim pengabdian juga melakukan pelatihan pengolahan telur ayam. Pengolahan menjadi telur pindang, telur asin, telur aneka rasa dan cara-cara pengawetan telur. Mitra bisa menjual telur dalam bentuk olahan sehingga tidak selalu dijual dalam bentuk mentah. Selain itu tim juga melakukan pelatihan pembuatan kompos dari kotoran ayam layer. Sehingga diharapkan kotoran ayam tidak terbuang sia-sia.
MONITORING DAN PENDAMPINGAN

\section{PEMELIHARAAN AYAM LAYER}

Dalam suatu kegiatan, monitoring dan pendampingan sangat diperlukan untuk mengetahui sejauh mana kegiatan telah berjalan, apakah sesuai dengan yang direncanakan atau tidak dan juga untuk mengetahui kendala dan hambatan yang timbul. Dengan adanya monitoring dan pendampingan kegiatan bisa dikontrol dan apabila masalah yang menghambat ditemui, bisa segera dilakukan tindakan untuk mengatasi masalah tersebut.

Monitoring dan pendampingan ayam ras petelur dilakukan mulai pemeliharaan ayam berumur 18 minggu sampai saat ini sudah berumur 34 minggu. Pendampingan dan monitoring pada awal pemeliharaan dilakukan hampir setiap tiga hari sekali karena pengabdian ini berhubungan dengan benda hidup yang masih rawan terserang penyakit. Pendampingan meliputi pelatihan dan pengarahan dari pembersihan kandang, desinfeksi, vaksinasi, pemberian pakan, minum, vitamin, obat dan sanitasi. Saat ini ayam 
sudah berumur 34 minggu, dalam keadaan sehat dengan mortalitas 0\% dan sudah produksi telur puncak $98 \%$. Ayam ras petelur sudah mulai belajar bertelur mulai umur 20 minggu. Hasil telur dijual dengan harga perkilo antara Rp.17.000-Rp.20.000,-. Sementara ini pembeli malah sudah datang sendiri ke lokasi kandang (dibeli dari penduduk sekitar).
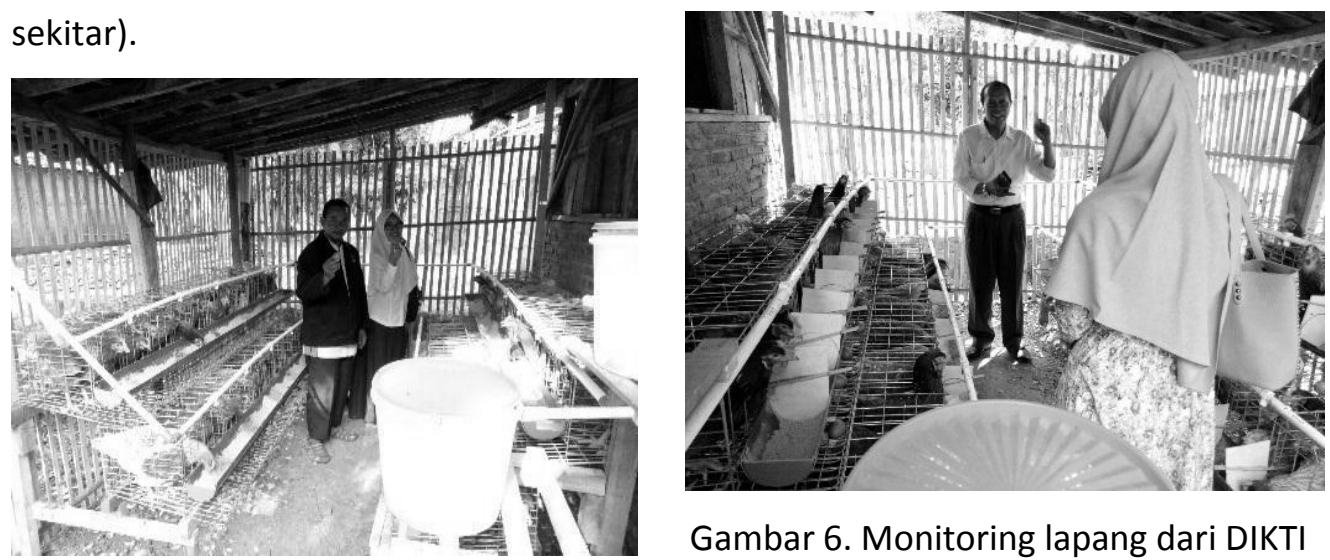

Gambar 6. Monitoring lapang dari DIKTI (7 September 2017)



Gambar 4. Produksi telur ayam ras di Panti asuhan An-Nahl 
MODAL BERJALAN

ce Pakan tiap hari

Co 120 gr $\times 100$ ekor $\times$ Rp 5

ce Vitamin \& Obat-obatan

$\leftrightarrow$ Tenaga (Bisa sendiri)

\& Penyusutan

Cos $100 \times$ Rp 6

\& TOTAL

HASIL TELUR

(s) Rata-rata $80 \%$

cos $80 \times \operatorname{Rp} 1.300$

HASIL USAHA PERHARI

RENCANA TAHAPAN BERIKUTNYA

Rencana yang akan dilakukan

untuk tahapan berikutnya untuk kedua mitra sendiri adalah menambah populasi ayam ras dengan membeli bibit baru. Dana pembelian bibit diambil dari keuntungan penjualan telur. Sedangkan rencana untuk tim pengabdian dan juga permintaan dari mitra adalah dibuatkan proposal baru untuk cara pembuatan konsentrat ayam petelur, sehingga kedepannya diharapkan mandiri dalam hal pakan, bisa menambah keuntungan dan tidak tergantung pakan jadi buatan pabrik.

\section{DAMPAK PENGABDIAN}

Setelah mendapatkan pelatihan dan penyuluhan tentang beternak ayam ras petelur, mitra terutama anak panti asuhan mengalami peningkatan dan tambahan ketrampilan, pengetahuan, selain keuntungan dari penjualan telur ayam ras. Bahkan kedua mitra ingin membesarkan usahanya dengan menambah bibit ayam ras, sehingga usaha beternak ayam ini menjadi berkelanjutan. Tidak hanya dampak pada anak panti asuhan saja akan tetapi guru pembimbing yang mendampingi merekapun seperti mendapatkan ide untuk usaha sampingan dirumah dengan beternak ayam ras, sehingga dampak pengabdian begitu luas dan sangat bermanfaat.

\section{KESIMPULAN}

1. Kemampuan dan ketrampilan anak panti asuhan An-Nahl dan YAUMIHA meningkat dan diharapkan mandiri secara ekonomis. Introduksi dan pemanfaatan kandang dan peralatan berjalan dengan sangat baik. Kandang dan bibit ayam layer di aplikasikan dengan baik. 
2. Produksi telur ayam ras yang berkelanjutan, kemampuan dalam pembukuan dan pemasaran produk juga meningkat. Pembukuan keuangan secara sederhana telah dibuat oleh kedua mitra.

\section{UCAPAN TERIMA KASIH}

Dengan telah selesainya kegiatan pengabdian dan penyusunan laporan ini, terimakasih yang tidak terhingga kami sampaikan kepada pihak-pihak yang telah memberi kesempatan untuk melakukan kegiatan dan memberi bantuan baik berupa dana, ijin dan partisipasi.

1. DIKTI

2. Lembaga Penelitian dan pengabdian Pada Masyarakat (LPPM) UNS

3. Panti Asuhan An-Nahl dan YAUMIHA di Kabupaten Sragen.
DAFTAR PUSTAKA

Amanah, S. 2007. Makna Penyuluhan Dan Transfornasi Perilaku Manusia. Jurnal Penyuluhan. Edisi Maret 2007. Vol. 3 No.1. ISSN : 1858-2624

Kementerian Kesehatan RI, 2010. Telur Sumber Makanan Bergizi. Jakarta. 


\section{BIODATA PENELITI}

Ratih dewanti, S.Pt., M.Sc.

Tenaga pendidik atau dosen di Fakultas Pertanian Universitas Sebelas Maret. Lahir di Bantul pada 31 Maret 1982. Saat ini mengampu mata kuliah Manajemen Ternak Unggas, IImu Ternak Unggas, Ilmu Produksi Aneka Ternak Unggas, Dasar Pemuliaan Ternak, IImu Pemuliaan Ternak, IImu Lingkungan dan Tingkah Laku Ternak, Biologi, Pengantar Ilmu Peternakan, Pengolahan Limbah Peternakan. Pengalaman penelitian dan pengabdian pada masyarakat diantaranya Pemberdayaan Anak Panti Asuhan An-Nahl Dan Yaumiha Di Kabupaten Sragen Melalui Ketrampilan Beternak Ayam Ras Petelur. 